https://doi.org/10.28925/2226-3012.2021.103

УДК 378 (477):005.6

\title{
Галина Калінічева
}

ORCID iD 00 00-0002-7978-1844

кандидат історичних наук, доцент,

старший науковий співробітник НДЛ освітології,

Київський університет імені Бориса Грінченка

вул. Тимошенка, 13-Б, 04212 Київ, Україна

h.kalinicheva@kubg.edu.ua

\section{ЯКІСТЬ ВИЩОЇ ОСВІТИ ЯК СКЛАДОВА ФОРМУВАННЯ ЛЮДСЬКОГО КАПІТАЛУ: ВИКЛИКИ ДЛЯ УКРАЇНИ}

\begin{abstract}
Актуалізовано проблему забезпечення якості вищої освіти для підготовки інновачійного людського капіталу, який сприяє підвищенню глобальної конкурентоспроможності України. Mета статті полягає у визначенні напрямів забезпечення якості вищої освіти для створення дієвих механізмів підвищення якості людського капіталу в університетському середовищі. Акцентовано увагу на глобальних викликах, детермінованих розбудовою цифрової економіки, пандемією COVID-19, інтернаціоналізацією освітнього простору. Проаналізовано проблеми неузгодженості системи вищої освіти та ринку праці в Україні, з'ясовано причини безробіття осіб з вищою освітою, трудової та освітньої міграчії. Вказано на необхідність системної модернізації та випереджального розвитку університетської освіти. Наголошено на необхідності безперервної освіти упродовж життя та формування нових компетентностей і неспеціалізованих, міжпрофесійних навичок (soft skills) задля підвищення конкурентоспроможності фахівців та якості людського капіталу. Запропоновано напрями забезпечення якості вищої освіти задля оптимізації внеску людського капіталу в інтелектуально-інновачійний потенціал країни.
\end{abstract}

Ключові слова: вища освіта; компетентність; конкурентоспроможність; людський капітал; модернізація, ринок праці; університет; якість вищої освіти.

Вступ. Актуальність проблеми полягає у тому, що суспільство знань, в якому провідними орієнтирами постають знання, інформація та інтелект, ставить на порядок денний принципово нові вимоги до рівня якості вищої освіти та фахової підготовки працівника. Університетська освіта на нинішньому етапі розвитку людської цивілізації має забезпечувати фахову підготовку конкурентоспроможного людського капіталу для високотехнологічного й інноваційного розвитку країни, задовольняючи потреби суспільства, держави та ринку праці у кваліфікованих фахівцях шляхом поєднання освіти з наукою та виробництвом. Саме в системі середньої та вищої освіти формується особистість, іiі світогляд, інтелектуальний, інноваційний та трудовий потенціал суспільства. Якісна вища освіта відіграє важливу роль у підготовці та розвитку людського капіталу, який спроможний забез- печити інноваційний поступ української держави. Адже рівень суспільного розвитку визначається людським фактором, рівнем фахової та моральної підготовки осіб, їх мотивацією та соціально-економічним становищем.

Сучасний розвиток людської цивілізації переконливо демонструє, що драйвером підвищення конкурентоздатності країни в глобальному вимірі нині виступають знання та інформація, що формують людський капітал. У стратегічному розумінні конкурентоспроможність держави визначається рівнем розвитку освіти і науки, якістю надання освітніх послуг на кожному рівні освіти, що детермінує необхідність ефективного оновлення освітньої системи з метою своєчасного й адекватного реагування на виклики часу, а також - й напрацювання на випередження. Водночас, актуальність порушеного питання детермінована потребами та змінами на ринку праці у зв'язку із глобаль- 
ною пандемією COVID-19, суперечливістю освітніх реформацій та їх навздогінним характером тощо.

Актуальні проблеми теорії людського капіталу розкрито в роботах таких американських вчених, як Г. Беккер, Е. Денісон, Дж. Кендрік, С. Кузнец, Ф. Махлуп, Д. Мінсер, Т. Шульц. Пізніше цією проблематикою зацікавилися європейські економісти. У дослідженнях Г. Барта, Г. Бартельса, С. Блека, М. Боона, Дж. Майрессе, С. Сассеноу, Г. Тена, В. Хоффмана та ін. знайшли відображення різні аспекти теорії людського капіталу. Починаючи 3 1990-х рр. ця проблема стала предметом наукових розвідок українських вчених - О. Амоші, В. Антонюк, Д. Богині, О. Грішнової, М. Долішнього, Г. Дмитренка, I. Каленюк, А. Колота, В. Куценко, Е. Лібанової, Д. Мельничука, С. Пирожкова, А. Чухна та ін.

Проблеми забезпечення якості вищої освіти порушувались у численних дослідженнях закордонних вчених у зв'язку із формуванням Європейського простору вищої освіти. Теоретико-методологічні складові підвищення конкурентоспроможності вищої освіти в процесі формування людського капіталу висвітлені у роботах таких зарубіжних вчених, як А. Бранденбургер, Е.Дж. Блейклі, Дж. Брекер, Д. Грін, I. Кірцнер, Дж. Мур, М. Портер, Д. Поланд, Л. Харві, Й. Шумпетер. Наукові студіювання вітчизняних науковців цієї проблеми активізувалися після входження України до Болонського процесу, участь у якому детермінувала забезпечення європейських стандартів якості вищої освіти в університетському середовищі. Серед численних наукових робіт, присвячених проблемам забезпечення якості вищої освіти, вартують роботи О. Александрової, Н. Батечко, Н. Віннікової, М. Гриценко, С. Калашнікової, М. Кісіля, В. Кременя, В. Лугового, О. Родіонова, В. Рябченка, О. Слюсаренко, В. Ткача, С. Шевченка, С. Шудло та ін.

Водночас, в українській соціогуманітаристиці існує чимало наукових розвідок, присвячених різним аспектам розвитку національної системи вищої освіти. В роботах В. Андрущенка, Н. Батечко, В. Бахрушина, М. Бойченка, Л. Горбунової, М. Дебич, Д. Дзвінчука, I. Драч, С. Заскалєти, В. Зінченка, В. Кременя, М. Култаєвої, С. Курбатова, О. Локшиної, В. Лугового, М. Михальченка, В. Огнев'юка, С. Пролєєва, О. Романовського, В. Рябченка, С. Сисоєвої, Н. Скотної, I. Степаненко,
Т. Фінікова, О. Шарова та багатьох інших дослідників проаналізовано широкий спектр актуальних проблем розвитку національної університетської освіти.

Попри наявність у вітчизняному науковому просторі широкого спектру досліджень фахівців різних галузей (економіки, соціології, педагогіки, філософії тощо), пов'язаних з проблемами розвитку трудового потенціалу, ролі вищої освіти у формуванні економіки знань, малодослідженою на сьогодні залишається проблема формування людського капіталу в системі інститутів соціалізації, зокрема потребують подальших наукових розвідок проблеми забезпечення якості вищої освіти в процесі підготовки та формування конкурентоспроможних високоінтелектуальних фахівців в пї системі.

Метою статті, з огляду на актуальність проблеми формування конкурентоспроможного людського капіталу в системі вищої освіти, $€$ визначення напрямів забезпечення якості вищої освіти для створення дієвих механізмів підвищення якості людського капіталу в університетському середовищі.

Методологія дослідження грунтується на міждисциплінарному підході, принципах комплексності, цілісності, історичності, системності, детермінізму, гуманізму, розвитку. У процесі наукового студіювання автором було застосовано методи аналізу, систематизації, порівняння, узагальнення, а також системноаналітичний, історико-генетичний та статистичний методи.

Модернізація вищої освіти як відповідь на виклики часу. Суспільство протягом свого існування, за баченням А. Дж. Тойнбі (2001), стикається із низкою проблем, які воно розв'язує у найбільш прийнятний для нього спосіб. Кожна така проблема - Виклик істоpiї (с. 30). В сукупності Виклики безпосередньо постають перед кожною країною, а в історичному вимірі кожна з країн задля досягнення успіху у своєму розвиткові послуговувалася розумом, що даний людству. Для більшості країн XXI століття характеризується інтелектуалізацією економічного і соціального життя, утвердженням у розвинених країнах знаннєвої економіки, що базується на знаннях, інноваціях, використанні інформаційних технологій.

Історичний досвід переконує, що не золотий запас, а інтелектуальний потенціал, науковотехнічні знання й їх технологічне застосування визначають сьогодні місце країни у світі та іï 
міжнародний рейтинг. Саме в університетських стінах відбувається формування інтелектуального капіталу, який безпосередньо залежить від якості вищої освіти. Розвиток якісної вищої освіти - це шлях до інноваційної економіки, яку ми розглядаємо як економіку інтелекту, освіти і науки, високої якості життя та людського капіталу.

Поширення в світі концепції «Industry 4.0», яка абсолютизує так зване "розумне» середовище і спирається на запровадження нового покоління інтернет-технологій i штучного інтелекту у виробничих процесах, спонукало до реалізації системної модернізації освітньої і наукової галузей в Україні, у першу чергу до забезпечення якості університетської освіти.

На кожному з етапів реформування вищої освіти питання забезпечення якості було на порядку денному. Так, вже на першому етапі (1991-2001 рр.) серед реформаційних новацій було проведення процедури ліцензування та акредитації напрямів (спеціальностей) підготовки фахівців; запровадження трьох освітньо-кваліфікаційних рівнів вищої освіти; розширення автономії закладів вищої освіти тощо. Другий етап (2002-2013 рр.) пов'язаний із ухваленням Закону України «Про вищу освіту» (2002), який закріпив попередні нововведення у вищій освіті, зокрема акредитацію закладів - I, II, III та IV рівнів, державний і галузевий стандарт вищої освіти тощо. Знаковими подіями цього періоду стали запровадження зовнішнього незалежного тестування та приєднання України у 2005 р. до Болонського процесу. У період 20022013 рр. було започатковано вертикальну (елітну) диференціацію закладів вищої освіти в Україні, що детермінувало виділення низки університетів із особливим статусом національного (розпочато ще з 1994 р.), уведенням статусу дослідницького національного університету (з 2009 р.), а також визначенням рейтингів закладів за міжнародними і національними університетськими рейтинговими системами. Загалом, ліберально-екстенсивний розвиток вищої освіти упродовж 1991-2013 рр. дедалі більше актуалізував необхідність комплексної системної модернізації університетської освіти з метою радикального підвищення ії якості та конкурентоспроможності в умовах глобалізаційних викликів та євроінтеграції.

Третій етап реформування вищої освіти (2014 - теперішній час) пов'язаний із ухва- ленням нового Закону України «Про вищу освіту» (2014 р.), в якому було закладено нові концептуальні підходи до модернізації національної університетської освіти в контексті запровадження ключових принципів та інструментів Болонського процесу зі створення привабливого й конкурентоспроможного Європейського простору вищої освіти та його інтеграції з Європейським дослідницьким простором. На порядку денному постали питання: забезпечення якості вищої освіти, зокрема функціонування сучасних систем внутрішнього забезпечення якості; університетська автономія; посилення дослідницької та інноваційної діяльності задля підготовки конкурентоспроможних на ринку праці фахівців; поглиблення рівня інтернаціоналізації вищої освіти тощо.

Сучасний етап розвитку вищої освіти актуалізує необхідність об'єднання зусиль університетів, держави, бізнесу (виробництва) задля активізації впровадження досліджень та інновацій; запровадження механізмів ефективного управління й фінансування у галузі вищої освіти. Починаючи з 2018 р., було створено нові стандарти вищої освіти та освітні програми на основі компетентнісного підходу. Окрім рівневої структуризації, вища освіта України зазнала також і галузевої трансформації: шляхом об'єднання й укрупнення освітнього і наукового переліків було введено новий Перелік галузей знань і спеціальностей (затверджено постановою Кабінету Міністрів України від 29 квітня 2015 р. № 266), який нині проходить чергову стадію оновлення й удосконалення.

Якість вищої освіти як чинник конкурентоспроможності. Критеріями визначення суспільно-економічної значущості освіти вважаються ефективність і якість. Ефективність, як правило, розглядається як економічна або економіко-управлінська категорія. Поняття якості охоплює, поряд з економічними, соціальні, пізнавальні та культурні аспекти освіти. Фактично, якість - це інтегральна характеристика освітньої діяльності та ії результатів. У ст 1, п. 23 Закону України «Про вищу освіту» (2014р.) якість вищої освіти визначається як відповідність результатів навчання вимогам, встановлених законодавством, відповідним стандартам освіти та/або договором про надання освітніх послуг. За баченням науковців, «якість освіти це ефективність роботи вищих навчальних закладів, яка значною мірою залежить від збалансованості факторів виробництва та раціональності менеджменту; соціально значимих 
для кадрових ресурсів норм, які зумовлюють і регулюють їх ставлення до роботи» (Гаращук, Куценко, 2015, с. 386).

Попри кардинальну зміну парадигми вищої освіти з огляду на характер глобальної інноваційної економіки, національна вища система так і не стала, на жаль, інкубатором не лише інноваційних розробок, а й технологічних компаній, які реалізовують ці ідеї. Так, до міжнародного рейтингу QS World University Ranking 2021 увійшло лише шість українських університетів: Харківський національний університет імені В.Н. Каразіна (477), Київський національний університет імені Тараса Шевченка (601650), Національний технічний університет «Харківський політехнічний інститут» (651700), Національний технічний університет «Київський політехнічний інститут імені Ігоря Сікорського» (701-750), Сумський державний університет (701-750), Національний університет «Львівська політехніка» (801-1000).

Сучасні заклади вищої освіти України продовжують існувати в старій індустріальній логіці, тримаючись за державне замовлення та відповідне фінансування. Вартою уваги вважаємо позицію Л. Червоної та О. Бульвінської, які наголошують на соціальній відповідальності університету перед суспільством та його зобов'язанні сприяти своєю діяльністю розв'язанню важливих соціальних проблем (подоланню соціальної нерівності, корупції, впровадженню технологічного прогресу, раціональному використанню ресурсів, охороні здоров'я, сприянні розв'язанню екологічних проблем тощо). Дослідниці обгрунтовують свою думку про те, що функціонування сучасного закладу вищої освіти полягає не тільки i не стільки у підготовці фахівців для економіки, скільки у важливості громадянських зобов'язань для стійкого розвитку суспільства. Зокрема, соціальна функція відтворення та суспільного розвитку, на думку дослідниць, можлива лише через імплементацію культурних норм у суспільне життя. При цьому варто враховувати мінливість історичних подій і процесів, оновлення суспільних відносин. I лише 3 огляду на загальний соціальний і культурний розвиток конкретного суспільства можна говорити про визначену соціальну відповідальність університетів (Червона, Бульвінська, 2021).

У 2012 р. групою американських експертів було підготовлено доповідь «Реформа американської освіти і національна безпека», в якій наголошувалося, що національна безпека визначається рівнем розвитку людського капіталу, який формується саме в системі освіти. Так, у доповіді було виокремлено п'ять основних загроз, які актуалізуються у разі зволікання з подоланням негативних тенденцій в освітній галузі: 1) загроза для економічного зростання і конкурентоспроможності; 2) загроза для воєнної безпеки; 3) загроза для інформаційної безпеки; 4) загроза для глобальних інтересів США; 5) загроза для єднання і згуртованості нації (Klein, Rice, Levy, 2012).

Аналіз, узагальнення та висновки, зроблені американськими фахівцями, є слушними і для українського сьогодення. Так, система національної вищої освіти певний час занадто повільно реагувала на зміну потреб суспільства у підвищенні якості людського капіталу. За роки незалежності політичний істеблішмент не розумів і не хотів бачити провідників суспільного розвитку. Влада повністю ігнорує роль людського капіталу в успішних суспільно-політичних трансформаціях. «Саме інтелектуально розвинена і креативна людина $€$ найбільшим багатством і найпотужнішим чинником розвитку будь-якої країни», - слушно наголошує В. Огнев'юк $(2016$, с. 38$)$.

Серед стримуючих чинників, які унеможливлювали розвиток інноваційної освітньої діяльності в Україні, можна виокремити наступні: 1) відсутність політичної волі до вироблення науково-обгрунтованої стратегії системних змін в освітній галузі; 2) невизначеність національних пріоритетів у науково-технічній галузі; 3) занадто повільні темпи розповсюдження та застосування інновацій; 4) недосконалість правових та економічних механізмів регулювання інноваційної діяльності та залишковий принцип іiі фінансування. Однією із ключових проблем $є$ відсутність або імітація системних реформ в економіці, відсутність чесної конкуренції у багатьох її галузях, що має негативний вплив на вищу освіту, оскільки часто саме ринок праці не стимулює якісну освіту.

Один із класиків загальної теорії формування людського капіталу Г. Беккер свого часу вказував на економічну ефективність освіти. У своєму дослідженні «Людський капітал: теоретичний та емпіричний аналіз», він довів взаємозв'язок між інвестуванням в освіту та доходами громадян (Becker, 1993). За його баченням, людський капітал підприємства являє собою сукупність навичок, знань та вмінь людини, витрати на отримання яких через освіту та внутрішнє корпоративне навчання 
можуть з часом принести значний прибуток як робітнику, так і його роботодавцю (Becker, 1978). Фундатор теорії людського капіталу Т. Шульц на підставі аналізу взаємозв'язку між рівнем освіти населення та його здатністю використовувати інформацію й технології 3 метою економічного розвитку, зробив висновок про взаємозв'язок добробуту людей із знаннями, які вони здобули. Подібно А. Сміту, він відстоював думку, що інвестиції в освіту $€$ не менш важливими, ніж капіталовкладення у машини та заводи (Shultz, 1961, 1971).

У спеціальному виданні «Звіт про глобальну конкурентоспроможність за 2020 рік: як просуваються країни до шляху одужання» зазначається, що рушієм економічного процвітання та продуктивності є людський капітал - можливості та навички людей, які реалізуються на ринку праці за допомогою продуктивної зайнятості. Вона розвивається через освіту протягом перших двох десятиліть життя окремої людини, а також за рахунок інвестицій у навчання в середині кар'єри. Виклики, поставлені пандемією COVID-19, детермінують необхідність переходу до активної політики ринку праці та ділової практики, яка поєднує освіту та охорону здоров'я з можливостями навчання (перенавчання) упродовж життя та формування необхідних на ринку праці компетентностей. Адекватність вищої освіти для задоволення потреб у зайнятості оцінюється у 68 балів (зі 100) у розвинених економіках та 55 балів (зі 100) у країнах, що розвиваються (The Global Competitiveness Report. Special edition 2020).

Згідно з Індексом глобальної конкурентоспроможності (Global Competitiveness Index, GCI) за 2017-2018 pp., Україна піднялася на 81 місце (з 137-ми) у порівнянні з 85 позицією у попередньому році. Вища освіта та підготовка як один із показників, що впливають на індекс конкурентоспроможності країни, мають вирішальний вплив на економічний розвиток і добробут суспільства. Проте освітні показники, наведені у Звіті, виявилися доволі суперечливими: за рівнем вищої освіти та професійної підготовки Україна посідала 35 місце, за охопленням середньою освітою Україна - 51 місце, за коефіцієнтом зарахування до закладів вищої освіти - 16 місце, проте за якістю вищої освіти - лише 56 місце. У 2019 р., за даними GCI, Україна втратила дві позиції й опустилася на 85-те місце з 141 країни, а за рівнем розвитку освіти Україна посідала 44 місце. У 2020 р. Україна, згідно з показниками GCI, посіла 92 місце серед 140 країн. В Індексі людського розвитку (Human Development Index, HDI) за 2020 рік Україна піднялася на 14 позицій та посідає 74 місце серед 189 країн.

Попри те, що Україна демонструє достатньо високі показники, що характеризують стан розвитку освіти, маємо зауважити, що освітні складові інтегральних індексів в основному відображають кількісні освітні характеристики, а відтак часто спотворюють уявлення про дійсний стан ефективності й якості освіти.

Вища освіта перед глобальними викликами. Пандемія COVID-19 у 2020-2021 pp. виявила низку системних проблем у підготовці фахівців для ринку праці. Так, перехід більшості населення на віддалену роботу під час пандеміі, актуалізував проблему дефіциту необхідних цифрових навичок та інших знань і вмінь у працівників, затребуваних новою економікою та технологічними змінами. Ринок праці демонструє все більший попит на фахівців із сучасними цифровими навичками, аналітичним і критичним мисленням, креативним підходом, вмінням ухвалювати нестандартні рішення, мислити стратегічно тощо. Тому в короткостроковій перспективі серед пріоритетів розвитку людського капіталу в усіх країнах світу, і в Україні зокрема, визначається оновлення навчальних систем для різних вікових груп та досвіду, з акцентом на навички, необхідні для створення нових робочих місць. Йдеться про підвищення кваліфікації, перекваліфікацію працівників в середині кар'єри та отримання ними нових навичок у поєднанні з активною політикою ринку праці.

Досвід розвинутих країн переконує, що стара парадигма освіти, згідно якої освіта була майданчиком для підготовки до життя, сьогодні себе вичерпала. Як слушно вказують Н. Батечко та М. Михайліченко (2020), пошук нової парадигми у вищій школі $є$ «цілковито об'єктивним явищем, зумовленим діалектичним розумінням трансформаційних процесів при переході від індустріального до постіндустріального й інформаційного суспільства, процесів глобалізації та інтеграції». Основними чинниками, які спонукають до зміни освітньої парадигми, за їхнім баченням, $€$ зростання освіти як фактору суспільного розвитку, зміна вимог до змісту, методів та форм навчального процесу, посилення процесу інтернаціоналізації, зміни організаційних форм освітньої діяльності та функціонування глобалізованого ринку освітніх послуг (с. 32, 33). 
Нині освіта $є$ способом життя: людина має постійно вчитися і навчатися, адже саме освіта упродовж життя захищає особистість від невизначеності, непередбачуваності та викликів сучасного світу. Просування соціальним ліфтом кожної особи залежить від якості отриманої освіти, а якість освіти - це, у першу чергу, якість знань. Зростання суспільного попиту на інтелектуальну працю, що заснована на застосуванні знань, аналітичних і комунікаційних здібностях, детермінує потребу у високоосвічених працівниках.

У довгостроковій перспективі трансформації економіки постає потреба в оновленні навчальних програм та розширенні інвестицій у формування компетентностей, які будуть затребуванні на ринку праці у недалекому майбутньому. «Щоб реалізувати таку трансформацію для створення робочих місць завтрашнього дня, економіки повинні постійно вдосконалювати технічне та професійне навчання та університетську освіту як для студентів, так і для робітників» - зазначається в Звіті глобальної конкурентоспроможності (The Global Competitiveness Report. Special edition 2020).

Швидке поширення цифровізації та запровадження нових технологій у всіх галузях економіки впливає на регулювання ринку праці, який мусить адаптуватися до нових форм роботи на робочих платформах в Інтернеті. Шлях екстенсивного розвитку національної системи вищої освіти себе повністю вичерпав. На часі - досягнення університетською освітою нових якісних характеристик, які відповідають вимогам сьогодення. Іншими словами, додана вартість при формуванні людського капіталу в системі вищої освіти має суттєво збільшуватися.

Проблеми та завдання національної вищої освіти задля здобуття актуальних й адекватних сьогоденню якісних характеристик. Серед існуючих в університетській освіті проблем, особливої уваги, за нашим баченням, заслуговують наступні: 1) відставання якості середньої і вищої освіти від вимог постіндустріальної економіки внаслідок недостатнього фінансування та копіювання зарубіжного досвіду; 2) слабкий зв'язок вищої освіти з потребами ринку праці та соціально-економічними проблемами розвитку національної економіки і суспільства в глобалізованому середовищі; 3) відсутність жорстких стандартів або їх недотримання в царині якості вищої освіти, економічної, правової та моральної відповідальності фахівців, що надають знаннємісткі послуги; 4) виклики євроінтеграційного поступу вищої освіти.

Зокрема, проблеми неузгодженості вищої освіти та ринку праці в Україні було грунтовно проаналізовано в Аналітичній записці Національного інституту стратегічних досліджень. Так, Л. Яценко (2020) слушно зауважує, що в Україні існує тісний взаємозв'язок між існуючими проблемами розвитку вищої школи та незавершеністю реформування практично усіх секторів національної економіки, що відбивається на якості формування та ефективності використання освітнього потенціалу та обумовлює неузгодженість пропозиції та попиту на ринку праці (с. 3).

Про це свідчать статистичні показники Державного центру зайнятості України: у січнічервні 2021 року послугами Державної служби зайнятості скористалися 856 тис. безробітних громадян, серед яких 52 \% зареєстрованих безробітних мали вищу освіту, $32 \%$ - професійнотехнічну, $16 \%$ - загальну середню освіту (для порівняння: у 2019 та 2020 рр. серед зареєстрованих безробітних в Україні 49 \% мали вищу освіту). За віковими групами: 27 \% зареєстрованих безробітних у 1 половині 2021 р. були у віці до 35 років; 28 - у віці від 35 до 44 років; $27 \%-$ у віці від 45 до 55 років; $18 \%$ - понад 55 років (тобто 82\% людей молодого й середнього віку). Попит та пропозиція робочої сили характеризується дисбалансом. Так, станом на 1 липня 2021 р., на одне вільне робоче місце претендувало 5 безробітних (на 1 липня 2020 р. - 9 осіб). У професійно-кваліфікаційному вимірі найбільша невідповідність попиту на робочу силу та іiї пропозиції була характерною для управлінців різних рівнів (службовців та керівників): на 1 вакансію претендувало 15 осіб.

Значна частина випускників українських закладів вищої освіти після завершення навчання або не працюють за спеціальністю, або зайняті на роботах нижче рівня кваліфікації, внаслідок чого суттєво втрачається інтелектуальний потенціал. Попри високу затребуваність кваліфікованих і конкурентоспроможних фахівців з боку підприємств, установ та організацій різних галузей економіки та форм власності, майже половина випускників 3 вищою освітою поповнюють лави безробітних або потребують перенавчання. Згідно з офіційними статистичними даними, понад 50\% випускників українських університетів мають дипломи бакалаврів та магістрів із суспільних наук, що свідчить про гіпертрофовану структуру під- 
готовки кадрів та унеможливлення інноваційної діяльності через недостатню орієнтованість на виробництво та підготовку фахівців для інноваційної діяльності.

Диспропорції між кількісними і якісними показниками, високий рівень безробіття серед осіб з вищою освітою свідчать про невідповідність якості підготовки фахівців у закладах вищої освіти потребам роботодавців, що, своєю чергою, призводить до структурного дисбалансу на ринку праці та низького рівня економічної активності випускників з університетським дипломом. Ми поділяємо думку Л. Яценка (2020), що існує кілька причин такого дисбалансу. Це і зниження вимог до вступників до університетів, це і відсутність ефективного моніторингу якості вищої освіти, це й інформаційна невизначеність перспектив ринку праці у професійному розрізі. Ці та інші причини $€$ причиною того, що вищою освітою поступово втрачаються функція та інструментарій інвестування у людський капітал задля підвищення індивідуальної конкурентоспроможності.

Натомість, у країнах з високою продуктивністю праці (Данія, Нідерланди, Німеччина, Норвегія, Швеція, Швейцарія) частка фахівців 3 вищою освітою серед працівників доволі висока, там цінуються знання, досвід, професійна компетентність. «..останнім часом у світі посилюється інтелектуалізація зайнятості в економіці, велика увага приділяється покращенню якісного складу працівників. Тому вкрай важливим і для України є забезпечення підвищення інтелектуального потенціалу країни, а також його ефективного використання», - зазначають експерти (Гаращук, Куценко, 2015, с. 383, 386).

3 огляду на те, що рівень безробіття за останні п'ять років серед населення з повною вищою освітою складав 7-8 \%, базовою вищою освітою -13,7-16,3 \% та неповною вищою освітою в межах 7-9 \%, актуалізується питання запровадження регулярного моніторингу компетентностей (фахових і загальних), яких потребують ринок праці і сучасні роботодавці, та здійснення на його основі регулярного корегування змісту навчально-освітніх програм та освітніх стандартів.

Водночас, окрім зазначених у додатку до диплому про вищу освіту набутих під час навчання загальних та фахових компетентностей, сучасний фахівець з університетською освітою - претендент на робоче місце - мусить мати й неспеціалізовані, міжпрофесійні нави- чки (soft skills), які демонструють когнітивні вміння та здібності, підприємницькі навички, які сприяють адаптації до нових умов, критичному мисленню, виконанню нестандартних завдань, готовності до самоорганізації, стійкості, прагненню до навчання та командної роботи, зміни сфери зайнятості тощо. Згідно 3 проведеними дослідженнями, найбільш затребуваними роботодавцями у майбутньому soft skills стануть: емоційний інтелект, вміння працювати в команді, навички вирішення комплексних проблем, здатність швидко навчатися, адаптивність/гнучкість, аналітичне, критичне, стратегічне мислення, управління проєктами, ініціативність/управління змінами (А. Зінченко, М. Саприкіна, 2016).

Топ-10 найактуальніших навичок для майбутнього десятиліття було представлено у звіті «The Future of Jobs Report 2020», який було опубліковано під час Всесвітнього економічного форуму в Давосі (2020). Так, роботодавці очікують, що до 2025 р. працівники матимуть навички аналітичного мислення та інноваційності; активного навчання і розробки стратегії навчання; розв'язання складних/комплексних проблем; критичного мислення та аналізу; креативності, оригінальності та ініціативності; лідерства та соціального впливу (The Future of Jobs Report 2020).

Зокрема, «розвиток критичного мислення вимагає урахування в освітньому процесі складності його феномену як мислення «високого рівня», що поєднує синтетичне й аналітичне, репродуктивне й продуктивне, теоретичне й практичне мислення», - вказує П. Саух (2021, c. 13).

Отже, з огляду на вищевказані проблеми, перед університетською освітою актуалізуються наступні завдання: 1) забезпечення високої якості освітніх послуг, їх відповідності світовим стандартам та потребам національного ринку праці; 2) забезпечення безперервності освітнього процесу та професійного вдосконалення; 3) перепідготовка кадрів і орієнтація закладів вищої освіти на підготовку фахівців, здатних забезпечувати новітні технологічні процеси; 4) інформатизація освіти, модернізація іiі методів та освітніх технологій; 5) оптимізація запровадження в освітній процес новітніх досягнень освіти і науки; 6) формування у студентів аналітичного й критичного мислення; 6) забезпечення і підтримки належної якості науково-педагогічних кадрів, від яких вирішальною мірою залежить якість вищої освіти. 
Однією із проблем українського сьогодення $є$ втрата освітнього потенціалу й деінтелектуалізація праці, що є результатом відсутності у політичної еліти стратегічного бачення розвитку України у XXI столітті. Свідченням цього $є$ приниження статусу інтелектуальної праці, руйнація наукових шкіл, еміграція інтелектуалів, зниження рівня освіченості та загальної культури населення, активна трудова міграція найкращих спеціалістів за кордон, деформована структура зайнятості населення, втрата зв'язку між українською наукою та виробництвом, орієнтованим на інноваційні технології.

Наприклад, зворотнім боком інтернаціоналізації освіти в Україні $\epsilon$ активна освітня еміграція, що переконливо доводить невідповідність якості сучасної університетської підготовки суспільним очікуванням. Нині наявність диплому про вищу освіту не $є$ гарантією працевлаштування в Україні з достатнім рівнем оплати праці, про що свідчать показники трудової міграції осіб з вищою освітою, які прагнуть знайти роботу в інших країнах. Сьогодні очевидною $€$ також проблема «відпливу мізків», коли талановиті й перспективні науковці й освітяни, не маючи належної підтримки для наукової та професійної самореалізації, залишають Україну і працевлаштовуються у більш розвинених країнах світу.

Мотивами еміграції української молоді 3 метою отримання вищої освіти, на думку фахівців, є: «висока якість навчання, можливість навчання у рейтингових закладах вищої освіти; перспективи отримання престижної роботи та постійного місця проживання» (Олешко, Ровнягін, 2020). Маємо вказати також і на відносно легкі умови вступу до іноземного закладу вищої освіти (немає необхідності складати тести ЗНО тощо); доступну вартість навчання та проживання; можливість удосконалення знання іноземної мови та безкоштовного навчання та/або отримання стипендій і грантів, а також доволі швидку адаптацію молоді у країні навчання.

3 кожним роком кількість молодих українців, які прагнуть отримати якісну освіту в країнах ЄС збільшується. Як зазначає О. Малиновська (2018), «...якщо десять років тому в $Є С$ навчалися трохи більше 10 тис. учнів та студентів-українців, то в 2015 р. їхня чисельність сягнула майже 43 тис. Лише протягом 2016 р. громадянам України було вперше оформлено 25,3 тис. дозволів на перебування в ЄС $з$ освітньою метою, з них 16,8 тис. у Польщі». Цьому сприяє й пропозиція зарубіжними країнами численних освітніх програм для українських студентів та створення умови для подальшого працевлаштування випускників, які успішно завершили навчання в національних навчальних закладах. «Евентуальний дефіцит працівників може стати гальмом розвитку економіки, а відтік найбільш активних, молодих та освічених осіб - демократичних перетворень в Україні» - наголошують експерти (Малиновська, 2018, с. 5, 10, 11).

Викликає занепокоєння факт освітньої еміграції і тому, що у вітчизняних закладах вищої освіти існує певний надлишок ліцензованих місць. Такий перебіг подій є загрозою для демографічного та економічного становища України, адже 3 огляду на вкрай несприятливу демографічну ситуацію в Україні, стрімке старіння ii населення, інтенсифікація трудової та освітньої міграції з подальшою еміграцією економічно активних громадян становить реальну загрозу для трудового та інтелектуального потенціалу нації й може перетворитися на реальний гальмівник економічного зростання. А європейські країни виконуватимуть стратегічне завдання конкурентоспроможності у світі за рахунок імміграції фахівців, у т.ч. й українських.

Реаліі жорсткого конкурентного середовища детермінують необхідність усвідомлення того, що вища освіта має унеможливити розпорошення ресурсів і мінімізувати неефективне використання людського капіталу.

\section{Висновки.}

1. У національній системі вищої освіти мають місце кількісні та якісні деформації, що впливають на іiі якість, ефективність і конкурентоспроможність. Тривалий екстенсивний шлях розвитку університетської освіти відбивається на кваліфікації випускників, знижуючи глобальну конкурентоспроможність України. Тому нагальним завданням системи вищої освіти на сучасному етапі має бути підвищення ii якості задля посилення внеску в розвиток інтелектуального та інноваційного потенціалу країни.

2. Забезпечення якості вищої професійної підготовки має слугувати формуванню конкурентоспроможного людського капіталу. Напрямами забезпечення якості вищої освіти на нинішньому етапі мають стати: створення ефективних механізмів гарантування якості вищої освіти; забезпечення концентрації університетського потенціалу та підвищення 
його глобальної конкурентоспроможності; узгодження структури та змісту підготовки фахівців з метою забезпечення потреб економіки України; приведення кількісного контингенту здобувачів вищої освіти у відповідність до реальної ресурсної бази вищої освіти та потреб ринку праці; оновлення змісту і форм вищої освіти 3 метою ефективної трудової діяльності; розвиток освіти упродовж життя.

3. Показниками забезпечення якості вищої освіти можна вважати: успішність здобувачів вищої освіти; здобуття необхідних фахових та загальних компетентностей через оновлення освітніх програм відповідно до потреб ринку праці; впровадження в навчальний процес інноваційних навчальних компонентів; розвиток математичної, комп'ютерної та медіаграмотності, формування цифрових навичок; здатність працівників постійно навчатися та швидко опановувати нові знання, вміння та навички.

4. Покращенню якості людського капіталу в Україні має слугувати приведення освітніх стандартів до потреб суспільного розвитку, професійно орієнтованих програм - для задоволення ринку праці. Унеможливити втрати людських ресурсів, спричинених еміграцією, можливо лише за умов успішного соціальнополітичного та економічного реформування та розвитку України.
5. Створити і розвивати конкурентоспроможну економіку, здатну забезпечувати гідний рівень життя населення, можна лише через високу якість освіти та здобуття знань, забезпечення їх безперервного трансферу в суспільстві і матеріалізації в техніці й технологіях. Найефективнішим способом забезпечення розвитку усієї господарської системи країни $€$ інвестиції у людський капітал.

6. Виклики економіки знань детермінують оновлення суспільних місій університету та впровадження інноваційних, прогресивних освітніх технологій, які слугуватимуть формуванню складових людського капіталу в системі університетської освіти та сприятимуть економічній конкурентоздатності країни та конкурентоспроможності майбутнього фахівця на ринку праці та відповідно - підвищенню якості його життя та суспільстві в цілому.

7. Ігнорування глобальних викликів і відсутність своєчасних адекватних відповідей несе загрози унеможливлення розбудови інноваційної економіки та зведення ролі України до постачальника природних та пюдських ресурсів.

Перспективи подальших досліджень полягають у здійсненні аналізу нормативно-правового забезпечення якості вищої освіти в Україні та визначенні дієвих механізмів регулювання якості в сучасному університеті.

\section{Список використаної літератури}

1. Батечко Н., Михайліченко М. Еволюція освітніх парадигм у сучасному науковому дискурсі. Освітологія. 2020. № 9. С. 29-37. DOI: https://doi.org/10.28925/2226-3012.2020.9.4

2. Гаращук О. В., Куценко В. І. Вища освіта України: траєкторія підвищення ії якості. Вісник Національного університету «Львівська політехніка». Менеджмент та підприємництво в Україні: етапи становлення і проблеми розвитку. 2015. № 819. С. 381-390.

3. Закон України «Про вищу освіту». URL: https://zakon.rada.gov.ua/laws/show/1556-18/ ed20170928\#n33 (дата звернення: 10.09.2021).

4. Зінченко А. Г., Саприкіна М. А. Навички для України 2030: Погляд бізнесу. Київ: Видавництво «ЮСТОН», 2016. 36 c.

5. Малиновська О. А. Трудова міграція громадян України за кордон: виклики та шляхи реагування. Аналітична записка НІСД. 2018. URL: https:/niss.gov.ua/doslidzhennya/socialna-politika/ trudova-migraciya-gromadyan-ukraini-za-kordon-vikliki-ta-shlyakhi (дата звернення: 12.09.2021).

6. Огнев’юк В. Освіта та конкурентоспроможність суспільства. Освітологія. 2016. № 5. С. 37-43. DOI: https://doi.org/10.28925/2226-3012.2016.5.3744

7. Олешко А. А., Ровнягін О. В. Сучасні тенденції міжнародної освітньої еміграції з України. Інвестиції: практика та досвід. 2020. № 3. C. 21-25. DOI: 10.32702/2306-6814.2020.3.21

8. Попит та пропозиція на зареєстрованому ринку праці у січні-червні 2021 року. Державний центр зайнятості. URL: https://www.dcz.gov.ua/analitics/67 (дата звернення: 20.09.2021).

9. Рябченко В. Протекціонізм некомпетентності як чинник блокування підвищення якості вітчизняної вищої освіти та зниження конкурентоспроможності України. International Scientific Journal 
of Universities and Leadership. 2020. № 9. C. 149-189. DOI: https://doi.org/10.31874/2520-6702-2020-9-1149-189

10. Саух П. Розвиток критичного мислення як провідний тренд сучасного освітнього процесу. Непервна професійна освіта: теорія і практика. 2021. № 2 (67). C. 7-15. DOI: https://doi. org/10.28925/1609-8595.2021.2.1

11. Ситуація на зареєстрованому ринку праці та діяльність Державної служби зайнятості у січні-червні 2021. Державний иентр зайнятості. URL: https://www.dcz.gov.ua/analitics/68 (дата звернення: 20.09.2021).

12. Стратегії вищої освіти в умовах інтернаціоналізації для стійкого розвитку суспільства: монографія / В. Зінченко та ін. ; за ред. В. Зінченка. Київ : Інститут вищої освіти НАПН України, 2020. 199 c. DOI: https://doi.org/10.31874/978-617-7486-36-6-2020

13. Тойнби А. Дж. Постижение истории. Москва: Рольф, 2001. 640 с.

14. Яценко Л. Д. Проблеми неузгодженості вищої освіти та ринку праці в Україні. Аналітична записка НІСД. Серія «Соціальна політика». 2020. № 14. URL: https://niss.gov.ua/sites/default/ files/2020-02/analit-yatsenko-social-policy-14-2020.pdf (дата звернення: 15.07.2021).

15. Aleksandrova O., Hroznyi I., Vinnikova N., Chuvasova N. Control of the quality assurance system at the modern Ukrainian university. Naukovyi Visnyk Natsionalnoho Hirnychoho Universytetu. 2019. № 2. P. 153-162. DOI: 10.29202/nvngu/2019-2/18.

16. Becker G. S. The Economic Approach to Human Behavior. Chicago: University of Chicago Press, 1978. $320 \mathrm{p}$.

17. Becker G. S. Human Capital: Theoretical and Empirical Analysis, with Special Reference to Education. Chicago: University of Chicago Press, 1993. 390 p.

18. Chervona L., Bulvinska O. Social and cultural determinants of the university social responsibility. Continuing Professional Education: Theory and Practice. 2021. № 2 (67). P. 25-31. DOI: https://doi. org/10.28925/1609-8595.2021.2.3

19. Global Competitiveness 2019. URL: http://www3.weforum.org/docs/WEF_TheGlobalCompetitiv enessReport2019.pdf (дата звернення 01.08.2021).

20. Human Development Index (HDI) Ranking. From the 2020 Human Development Report. URL: http://hdr.undp.org/en/content/latest-human-development-index-ranking (дата звернення 10.08.2021).

21. Klein J. I., Rice C., Levy J. C. U.S. Education Reform and National Security (Independent Task Force Report No. 68). New York: Council on Foreign Relations Press. March 2012. 120 p.

22. QS World University Rankings 2021. URL: https://www.topuniversities.com/university-rankings/ world-university-rankings/2021 (дата звернення 05.09.2021).

23. Schultz T. W. Investment in Human Capital. The American Economic Review. 1961. Vol. 51. № 1. P. $1-17$.

24. Shultz T. Investment in Human Capital. New York: The Free Press, 1971. 272 p.

25. The Future of Jobs. Employment, Skills and Workforce Strategy for the Fourth Industrial Revolution. World Economic Forum. 2016. URL: http://www3.weforum.org/docs/WEF_Future_of_Jobs.pdf. (дата звернення: 25.09.2021).

26. The Future of Jobs Report 2020. World Economic Forum. 20 October 2020. URL: https://www. weforum.org/reports/the-future-of-jobs-report-2020/in-full/chapter-2-forecasts-for-labour-marketevolution-in-2020-2025 (дата звернення 25.09.2021)

27. The Global Competitiveness Report 2017-2018. URL: https://www.weforum.org/reports/theglobal-competitiveness-report-2017-2018 (дата звернення 05.09.2021).

28. The Global Competitiveness Report. Special edition 2020: How Countries are Performing on the Road to Recovery. URL: https://www.weforum.org/reports/the-global-competitiveness-report-2020/ digest\#report-nav (дата звернення 05.09.2021)

29. The Human Capital Index 2020 Update. Human Capital in the Time of COVID-19. URL: https:// openknowledge.worldbank.org/handle/10986/34432 (дата звернення 05.09.2021). 


\section{References}

Batechko, N. \& Mykhailichenko, M. (2020). Evolyuciya osvitnih paradigm u suchasnomu naukovomu diskursi [Evolution of educational paradigms in modern scientific discourse]. Osvitolohiya, 9, 29-37. https://doi.org/10.28925/2226-3012.2020.9.4

Garashchuk, O. V., Kutcenko, V. I. (2015). Visha osvita Ukrayini: trayektoriya pidvishennya yiyi yakosti [Higher education in ukraine: directions of its quality improvement]. Visnik Nacionalnogo universitetu «Lvivska politehnika». Menedzhment ta pidpriyemnictvo $v$ Ukrayini: etapi stanovlennya i problemi rozvitku, 819, 381-390.

Zakon Ukrainy «Pro vyshchu osvitu» [Law of Ukraine On Higher Education] (2014). https://zakon.rada.gov. ua/laws/show/1556-18

Zinchenko, A. G., Saprikina, M. A. (2016). Navichki dlya Ukrayini 2030: Poglyad biznesu [Skills for Ukraine 2030: A look at business]. YuSTON.

Malinovska, O. A. (2018). Trudova migraciya gromadyan Ukrayini za kordon: vikliki ta shlyahi reaguvannya [Labor migration of Ukrainian citizens abroad: challenges and ways to respond]. Analitichna zapiska Nacionalnogo institutu strategichnih doslidzhen. https://niss.gov.ua/doslidzhennya/ socialna-politika/trudova-migraciya-gromadyan-ukraini-za-kordon-vikliki-ta-shlyakhi

Ogneiuuk, V. Osvita ta konkurentospromozhnist suspilstva [Education and competitiveness of society]. Osvitolohiya, 5, 37-43. https://doi.org/10.28925/2226-3012.2016.5.3744

Oleshko, A., Rovnyagin, A. (2020). Suchasni tendenciyi mizhnarodnoyi osvitnoyi emigraciyi z Ukrayini [Modern tendencies in international educational emigration from Ukraine]. Investytsiyi: praktyka ta dosvid, 3, 21-25. 10.32702/2306-6814.2020.3.21

Popit ta propoziciya na zareyestrovanomu rinku praci u sichni-chervni 2021 roku [Demand and supply in the registered labor market in January-June 2021] (2021, September, 17). Derzhavnij centr zajnyatosti. https://www.dcz.gov.ua/analitics/67

Ryabchenko, V. (2020). Protekcionizm nekompetentnosti yak chinnik blokuvannya pidvishennya yakosti vitchiznyanoyi vishoyi osviti ta znizhennya konkurentospromozhnosti Ukrayini [Protectionism of incompetence as a factor in blocking the improvement of the quality for domestic higher education]. International Scientific Journal of Universities and Leadership, 9, 149-189. https://doi. org/10.31874/2520-6702-2020-9-1-149-189

Saukh, P. (2021). Rozvitok kritichnogo mislennya yak providnij trend suchasnogo osvitnogo procesu [Development of critical thinking as a leading trend in the modern educational process]. Continuing Professional Education: Theory and Practice, (2), 7-15. https://doi.org/10.28925/1609-8595.2021.2.1

Situaciya na zareyestrovanomu rinku praci ta diyalnist Derzhavnoyi sluzhbi zajnyatosti u sichni-chervni 2021 [The situation on the registered labor market and the activities of the State Employment Service in JanuaryJune 2021] (2021, September, 15). Derzhavnij centr zajnyatosti. https://www.dcz.gov.ua/analitics/68

Zinchenko, V. (Ed.) (2020). Strategiyi vishoyi osviti v umovah internacionalizaciyi dlya stijkogo rozvitku suspilstva: monografiya [Strategies of higher education in the conditions of internationalization for sustainable development of society: monograph]. Institut vishoyi osviti NAPN Ukrayini. https:// doi.org/10.31874/978-617-7486-36-6-2020

Toynbee, A. J. (2001). Postizhenie istorii [A Study of History]. Rolf.

Yatsenko, L. D. (2020). Problemi neuzgodzhenosti vishoyi osviti ta rinku praci v Ukrayini [Problems of inconsistency between higher education and the labor market in Ukraine]. Analitichna zapiska NISD. Seriya «Socialna politika», 14. https://niss.gov.ua/sites/default/files/2020-02/analityatsenko-social-policy-14-2020.pdf

Aleksandrova, O., Hroznyi, I., Vinnikova, N., Chuvasova, N. (2019). Control of the quality assurance system at the modern Ukrainian university. Naukovyi Visnyk Natsionalnoho Hirnychoho Universytetu, 2, 153-162. 10.29202/nvngu/2019-2/18.

Becker, G. S. (1978). The Economic Approach to Human Behavior. University of Chicago Press.

Becker, G. S. (1993). Human Capital: Theoretical and Empirical Analysis, with Special Reference to Education. University of Chicago Press.

Chervona, L., Bulvinska, O. (2021). Social and cultural determinants of the university social responsibility. Continuing Professional Education: Theory and Practice, 2 (67), 25-31. https://doi. org/10.28925/1609-8595.2021.2.3 
Global Competitiveness (2019). http://www3.weforum.org/docs/WEF_TheGlobalCompetitivenessRepo rt2019.pdf

Human Development Index (HDI) Ranking. From the 2020 Human Development Report. http://hdr.undp.org/ en/content/latest-human-development-index-ranking

Klein, J. I., Rice, C., Levy, J. C. (2012). U.S. Education Reform and National Security (Independent Task Force Report No. 68). Council on Foreign Relations Press.

QS World University Rankings 2021. https://www.topuniversities.com/university-rankings/world-universityrankings/2021

Schultz, T. W. (1961). Investment in Human Capital. The American Economic Review, 51 (1), 1-17.

Shultz, T. (1971). Investment in Human Capital. The Free Press.

The Future of Jobs. Employment, Skills and Workforce Strategy for the Fourth Industrial Revolution (2016). World Economic Forum. http://www3.weforum.org/docs/WEF_Future_of_Jobs.pdf

The Future of Jobs Report 2020. World Economic Forum (20 October 2020). https://www.weforum.org/reports/ the-future-of-jobs-report-2020/in-full/chapter-2-forecasts-for-labour-market-evolutionin-2020-2025

The GlobalCompetitiveness Report2017-2018. https://www.weforum.org/reports/the-global-competitivenessreport-2017-2018

The Global Competitiveness Report. Special edition 2020: How Countries are Performing on the Road to Recovery (2020). World Economic Forum. https://www.weforum.org/reports/the-globalcompetitiveness-report-2020/digest\#report-nav

The Human Capital Index 2020 Update. Human Capital in the Time of COVID-19. https://openknowledge. worldbank.org/handle/10986/34432

\title{
JAKOŚĆ SZKOLNICTWA WYŻSZEGO JAKO KOMPONENT FORMOWANIA KAPITAŁU LUDZKIEGO: WYZWANIA DLA UKRAINY
}

\author{
Kaliniczewa Galyna \\ ORCID iD 00 00-0002-7978-1844 \\ Kandydat nauk historycznych, Profesor nadzwyczajny, \\ starszy pracownik naukowycnaukowo-badawczego Laboratorium Oświatologii, \\ Kijowski uniwersytet imienia Borysa Grinczenki \\ 13-B, ulica Tymoszenko, 04212 Kijów, Ukraina \\ h.kalinicheva@kubg.edu.ua
}

Podniesiono problem zapewnienia jakości szkolnictwa wyższego dla przygotowania innowacyjnego kapitału ludzkiego, który przyczynia się do wzrostu globalnej konkurencyjności Ukrainy. Celem artykułu jest identyfikacja obszarów zapewniania jakości w szkolnictwie wyższym w celu stworzenia efektywnych mechanizmów podnoszenia jakości kapitału ludzkiego w środowisku uniwersyteckim. Nacisk kładziony jest na globalne wyzwania determinowane przez rozwój gospodarki cyfrowej, pandemię COVID-19 oraz internacjonalizację przestrzeni edukacyjnej. Analizowane sa problemy niezgodności systemu szkolnictwa wyższego z rynkiem pracy na Ukrainie, wyjaśniane są przyczyny bezrobocia osób z wyższym wykształceniem, migracji zarobkowej i edukacyjnej.

Wskazana jest potrzeba systematycznej modernizacji i zaawansowanego rozwoju szkolnictwa wyższego. Nacisk kładziony jest na potrzebę uczenia się przez całe życie oraz kształtowania nowych kompetencji i niewyspecjalizowanych umiejętności międzyzawodowych (soft skills) w celu zwiększenia konkurencyjności profesjonalistów i jakości kapitału ludzkiego. Proponowane sq kierunki zapewnienia jakości szkolnictwa wyższego w celu optymalizacji wkładu kapitału ludzkiego w potencjał intelektualny i innowacyjny kraju.

Słowa kluczowe: szkolnictwo wyższe; kompetencje, konkurencyjność; kapitał ludzki; modernizacja; rynek pracy; uczelnia; jakość szkolnictwa wyższego. 


\title{
QUALITY OF HIGHER EDUCATION AS A COMPONENT OF HUMAN CAPITAL FORMATION: CHALLENGES FOR UKRAINE
}

\author{
Kalinicheva Halyna \\ ORCID iD 00 00-0002-7978-1844 \\ $\mathrm{PhD}$ of Historical Sciences, Associate Professor, \\ Senior Researcher of Scientific-Research Laboratory of Educology, \\ Borys Grinchenko Kyiv University, 13-B, Tymoshenko street, 04212 Kyiv, Ukraine \\ h.kalinicheva@kubg.edu.ua
}

The research actualizes problem of ensuring the quality of higher education for the preparation of innovative human capital, which contributes to increasing the global competitiveness of Ukraine. The purpose of the article is to identify areas for quality assurance in higher education to create effective mechanisms for improving the quality of human capital in the university environment. The paper pays attention to global challenges, that determined by the development of the digital economy, the COVID-19 pandemic, and the internationalization of the educational space. Author analyzes the problems of inconsistency between the system of higher education and the labor market in Ukraine, the reasons for unemployment of persons with higher education, peculiarities labor and educational migrations.

The need for systematic modernization and advanced development of university education is pointed out. Emphasis is placed on the need for lifelong learning and the formation of new competencies and non-specialized, interprofessional skills (soft skills) to increase the competitiveness of professionals and the quality of human capital. Author proposes the directions of ensuring the quality of higher education in order to optimize the contribution of human capital to the intellectual and innovative potential of the country.

Keywords: higher education; competence; competitiveness; human capital; modernization; labor marke; university; quality of higher education. 